\title{
Colostral Proline-Rich Polypeptide Complexes. Comparative Study of the Antioxidant Properties, Cytokine-Inducing Activity, and Nitric Oxide Release of Preparations Produced by a Laboratory and a Large-Scale Method
}

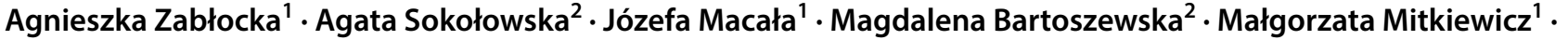 \\ Maria Janusz ${ }^{3} \cdot$ Tadeusz Wilusz $^{2} \cdot$ Antoni Polanowski
}

Accepted: 13 June 2019 / Published online: 22 June 2019

(c) The Author(s) 2019

\begin{abstract}
Colostral proline-rich polypeptide complex (PRP) with immunoregulatory and procognitive activities shows beneficial effects in Alzheimer's disease (AD). As the laboratory method of isolating PRP is expensive, laborious, and time consuming, a new large-scale methanol method of PRP isolation was developed. The proline-rich polypeptide complex obtained by this new method (named methanol PRP-MPRP) from both ovine or bovine colostra shows psychotropic activity and inhibitory effect on amyloid $\beta$ aggregation similar to those produced by the laboratory-scale method. The comparative study of the antioxidant properties, cytokine-inducing activity, and nitric oxide release of PRP and MPRP showed that preparations are biologically active, moreover MPRP should be used at concentration higher than $100 \mu \mathrm{g} / \mathrm{ml}$ to obtain results comparable to PRP.
\end{abstract}

Keywords Proline-rich polypeptide complexes $\cdot$ PRP $\cdot$ MPRP $\cdot$ Cytokines $\cdot$ Nitric oxide $\cdot$ Antioxidant activity

\section{Introduction}

Very substantial progress in elucidating the molecular mechanisms of the pathogenesis of neurodegenerative disorders allowed considering a new group of compounds with therapeutic significance as promising agents for modulation of the growth and function of central nervous system (CNS) cells (Barger et al. 1995; Vitkovic et al. 2000, 2001; Maccioni et al. 2001; Mattson 2004; Parihar and Hemnani 2004; Steinman 2008; Lynch 2014; Weiner et al. 2017). Upon activation, glial cells are able to secrete immunomodulatory factors that activate immunologically competent peripheral

Agnieszka Zabłocka

agnieszka.zablocka@hirszfeld.pl

1 Laboratory of Signal Transduction, Hirszfeld Institute of Immunology and Experimental Therapy, Polish Academy of Sciences, ul. R. Weigla 12, 53-114 Wrocław, Poland

2 Faculty of Biotechnology, University of Wrocław, F. Joliot-Curie 14a, 50-383 Wrocław, Poland

3 Department of Immunochemistry, Hirszfeld Institute of Immunology and Experimental Therapy, Polish Academy of Sciences, ul. R. Weigla 12, 53-114 Wrocław, Poland cells as well as glial cells themselves. The bidirectional communication between lymphoid cells and glial cells within the CNS occurs via various mediators, including cytokines and NO. The function of this mediators as well as the regulation of their secretion and activity have become subjects of intensive study (Aarli 2003; Lindberg et al. 2005). Any substance with antioxidant, NO, and cytokine regulatory properties could exert therapeutic effects in neurodegenerative disorders such as Alzheimer's disease (AD). A very promising example of a preparation with these properties are prolinerich polypeptide complexes (PRPs).

A complex of proline-rich polypeptides (PRP) was discovered and first isolated from ovine colostrum by Janusz et al. (1974). Similar complexes were subsequently found in human, cow, and goat colostra (Piasecki et al. 1997; Kruzel et al. 2004; Sokołowska et al. 2008). The properties of bovine PRP, named later Colostrinin ${ }^{\mathrm{TM}}{ }^{1}$, indicated that it is a very promising and nontoxic preparation with a potential use as a drug in neurological disorders. The potential value of the proline-rich polypeptide complex in the treatment of $\mathrm{AD}$ was shown for the first time in a

\footnotetext{
${ }^{1}$ Colostrinin is a Registered Trademark of ReGen Therapeutics Lim-
} ited, London. 
double-blinded placebo-controlled trial and a long-term open-label study (Leszek et al. 1999, 2002) and confirmed in multicenter clinical trials (Bilikiewicz and Gaus 2004).

Results of the clinical trials correlated well with the effect of PRP on incidental memory improvement and cognitive abilities in aged rats (Popik et al. 1999) and enhancement of long-term memory in one-day-old chickens trained on a weak passive-avoidance learning paradigm (Steward and Banks 2006). A very important activity of PRP is the prevention of $A \beta$ aggregation and the disruption of aggregates already existing (Schuster et al. 2005; Janusz et al. 2009). PRP increases neurite outgrowth in a dose-dependent manner as demonstrated in a cell differentiation model system of pheochromocytoma PC12 cells (Basci et al. 2005; Zabłocka et al. 2014). PRP is considered as a promising pharmacological agent, due to its ability to suppress uncontrolled microglial activation. An inhibitory effect on the differentiation/maturation of cells of the monocyte/macrophage lineage was also shown (Kubis et al. 2005).

Despite therapeutic evidence, the exact mechanism of PRP action in Alzheimer's disease is not yet fully clarified. PRP was initially found to show immunomodulatory activity affecting the maturation and differentiation of murine thymocytes (Janusz and Lisowski 1993), the production of interferon gamma (IFN- $\gamma$ ), tumor necrosis factor alpha (TNF- $\alpha$ ), interleukin 6 (IL-6), and other cytokines (Inglot et al. 1996; Zabłocka et al. 2001, 2007). PRP and one of its peptide components, nonapeptide (NP), inhibit the superoxide anion and nitric oxide production induced by LPS in mice in vivo (Zabłocka et al. 2005). It was shown that some PRP's constituent peptides, similarly to the whole polypeptide complex, induce cytokine secretion and proliferation of peripheral blood leukocytes (Stanton et al. 2001). PRP decreases the intracellular oxidative stress level, reduces 4-hydroxynonenal (4HNE)-mediated cellular damage, and suppresses 4HNE-induced cellular signaling in cultured cells (Boldogh et al. 2003; Zablocka and Janusz 2012). PRP induces signaling pathways and modulates gene expression in cellular redox regulation as well as cell proliferation and differentiation (Basci et al. 2005, 2007; Boldogh and Kruzel 2008). Oxidative stress as an early event is a key factor in the pathogenesis of $\mathrm{AD}$ and therapeutic strategies should therefore emphasize antioxidant agents (Lovell et al. 1997; Zhu et al. 2004; Wang et al. 2014).

Due to the costly, laborious, and time-consuming method of PRP isolation on a laboratory scale, a simple and fast method of separating proline-rich polypeptide complex from colostrum on a large scale was developed (Kruzel et al. 2004). So far it has been shown in many experiments that the newly made PRP preparations obtained from both ovine and bovine colostra very much resemble that isolated by the previous method in terms of inhibition of $\mathrm{A} \beta$ aggregation and psychotropic activity (Basci et al. 2005; Bourhim et al. 2007; Steward and Banks 2006; Boldogh and Kruzel 2008).

In this manuscript we present the results of a comparative study of biological activity of proline-rich polypeptide complex prepared by both methods: laboratory by Janusz et al. (1981) (PRP), and large-scale methanol method by Kruzel et al. (2004) (MPRP). The impact on cytokine secretion, nitric oxide release, and antioxidant properties was determined. The result obtained showed that both PRP and MPRP preparations are biologically active, moreover MPRP, to obtain results comparable to PRP, should be used at concentration higher than $100 \mu \mathrm{g} / \mathrm{ml}$.

\section{Materials and Methods}

\section{Reagents}

Proline-rich polypeptide complex preparations (PRPs) were prepared in Faculty of Biotechnology, University of Wrocław. Proline-rich polypeptide complex preparations (PRPs) were isolated from ovine and bovine colostra in both according to Janusz et al. (1981) and using the modified method of methanol extraction published in details by Kruzel et al. (2004). Preparations for the purpose of this manuscript, "PRP" was adopted for a preparation obtained by Janusz's method (1981) and "MPRP" (methanol PRP) for that separated by the methanol procedure of Kruzel (2004).

RPMI 1640 medium was obtained from the Laboratory of general Chemistry IITD, PAS. Tissue culture plates were from Costar. Leukoagglutinin (PHA), bacterial lipopolysaccharide (LPS) from E. coli (serotype 055:B5), ABTS, BCA kit, L-glutamine, and antibiotics (penicillin/streptomycin mixture) were obtained from Sigma. Fetal bovine serum (FBS) was obtained from Gibco BRL. Human IL-1 $\beta$, IL-6, IL-10, and TNF- $\alpha$ Elisa Sets were purchased from Becton-Dickinson Biosciences Pharmingen.

\section{Materials}

Blood samples were collected from healthy donors and kindly provided by the Station of Blood Donation, 4th Military Hospital, Wrocław, Poland.

The murine J774A.1 macrophage cell line was obtained from the ATCC (American Type Culture Collection). Cells in RPMI 1640 medium supplemented with 10\% heat-inactivated fetal bovine serum (FBS), $2 \mathrm{mM}$ L-glutamine, and antibiotics (penicillin, streptomycin) were cultured at $37^{\circ} \mathrm{C}$ in a humidified atmosphere of $95 \%$ air and $5 \% \mathrm{CO}_{2}$ unless otherwise indicated. 


\section{SDS-PAGE}

SDS/polyacrylamide slab gels (12\%) were prepared by the use of TXG Fast Cast Acrylamide solutions (Bio-Rad, California, USA). The protein samples were diluted with the buffer containing dithiothreitol as reducing reagent and loaded on to gel slabs. At the end of analysis gel slabs were stained with Coomassie Brilliant G -250.

\section{Cytokine Induction in Human Whole Blood Cell Cultures}

Cytokine secretion was induced according to the procedure described by Inglot et al. (1996). Blood samples from at least ten donors were collected into syringes containing sodium heparin. Within $1 \mathrm{~h}$ after the collection the blood was diluted with RPMI 1640 medium supplemented with penicillin/ streptomycin, L-glutamine, and 2\% FBS. One-ml portions of the cell suspension were distributed into 24-well flatbottomed tissue culture plates and the examined inducers (PRP and MPRP) at doses of 5, 50, and $100 \mu \mathrm{g}$ per $100 \mu \mathrm{l}$ of RPMI 1640 were added. The inducers $(2 \mu \mathrm{g} / \mathrm{ml}$ of PHA and $2 \mu \mathrm{g} / \mathrm{ml}$ of LPS) were used as a positive control. Wells containing untreated blood cell samples were used to measure the spontaneous production of cytokines (negative control). The plates were incubated for $20 \mathrm{~h}$ at $37{ }^{\circ} \mathrm{C}$ in a $5 \% \mathrm{CO}_{2}$ atmosphere. After incubation, the plates were centrifuged at $200 \times g$ for $15 \mathrm{~min}$. at room temperature. The supernatants were collected and used for the determination of cytokines.

\section{Determination of Cytokines}

The interleukins IL-1 $\beta$, IL- 6 , and IL-10 and TNF- $\alpha$ were determined by a microplate ELISA using commercially available ELISA sets from Becton-Dickinson according to the procedure recommended by the manufacturer.

\section{Nitrite/Nitrate Generation}

J774 cells were plated in 48 -well culture plates at $1 \times 10^{6}$ cells $/ \mathrm{ml} /$ well and cultured for $24 \mathrm{~h}$ with or without PRP/ MPRP $(10$, or $100 \mu \mathrm{g} / \mathrm{ml})$ or $2 \mu \mathrm{g} / \mathrm{ml}$ of LPS in $5 \% \mathrm{CO}_{2}$. To determine the effect of PRP/MPRP on nitric oxide induction, PRP/MPRP in concentrations of 10 and $100 \mu \mathrm{g} / \mathrm{ml}$ of cell culture were added simultaneously with LP $8 \mathrm{~h}$ before or after the induction. After incubation the plates were centrifuged at $200 \times g$ for $5 \mathrm{~min}$ at $4{ }^{\circ} \mathrm{C}$ and the level of nitric oxide in the supernatants was determined.

\section{Nitrite/Nitrate Determination}

Nitrite and nitrate levels were measured in the supernatants after the reduction of nitrate to nitrite with NADPH nitrate reductase as described by Guevara et al. (1998) and Moshage et al. (1995) with some modifications. In short, $100-\mu \mathrm{l}$ samples of supernatant were incubated for $45 \mathrm{~min}$ at $37{ }^{\circ} \mathrm{C}$ with nitrate reductase $(25 \mathrm{mU} / \mathrm{sample})$ in $20 \mathrm{mM}$ Tris buffer, $\mathrm{pH}$ 7.6. The total volume of the reaction mixture was $300 \mu$ l. After the enzymatic conversion, the nitrite concentration in the supernatant was measured using Griess reagent (0.1\% N-(1-naphthyl)-ethylenediamine dihydrochloride and $1 \%$ sulfanilamide in 5\% phosphoric acid). After $10 \mathrm{~min}$ of incubation at room temperature, the absorbance at $550 \mathrm{~nm}$ was measured. The concentration of nitrite was calculated from an $\mathrm{NaNO}_{2}$ standard curve.

\section{Cell Viability}

J774 cells were cultured in $75-\mathrm{cm}^{2}$ flasks at $37{ }^{\circ} \mathrm{C}$ in a $95 \%$ humidified atmosphere and 5\% $\mathrm{CO}_{2}$ in RPMI 1640 medium supplemented with $10 \%$ fetal bovine serum, $50 \mathrm{U} / \mathrm{ml}$ penicillin/streptomycin, and $2 \mathrm{mM} \mathrm{L-glutamine.} \mathrm{Viability} \mathrm{of} \mathrm{cells}$ incubated $24 \mathrm{~h}$ in the presence and in the absence of PRP/ MPRP was assessed by the trypan blue exclusion assay. Cells $\left(1 \times 10^{4}\right)$ were treated with $0.4 \%$ trypan blue stain for $15 \mathrm{~min}$. Trypan blue unstained cells (live) and stained (dead) cells were counted in a hemocytometer in three selected fields and averaged. The proportion of dead cells was calculated as the percentage of the total number of counted cells.

\section{TEAC Assay}

Trolox, a water-soluble analog of vitamin E, scavenges free radicals and provides protection from a mild form of oxidative stress. The Trolox Equivalent Antioxidant Capacity (TEAC) assay is based on the suppression of the absorbance of radical cations of 2,2'-azinobis(3-ethylbenzothiazoline 6-sulfonate) (ABTS) by antioxidants in the test sample. TEAC is widely applied to assess the amount of radicals that can be scavenged by antioxidant, i.e. the antioxidant capacity. To measure the antioxidant activity of the PRP samples, the method of Arts et al. (2004) with some modifications was used. Since the PRP preparations constitute a mixture of peptides, the potent antioxidant's concentration in $\mu \mathrm{g}$ rather than $\mu \mathrm{M}$ of polypeptide was evaluated. The experimental conditions were adapted for a 96-well microplate (rather than a cuvette). To a fixed concentration of a potent antioxidant (1.25 $\mu \mathrm{g}$ per $10-\mu \mathrm{l}$ sample), $290 \mu \mathrm{l}$ of ABTS ${ }^{\bullet}$ solution in increasing concentrations $(0-45 \mu \mathrm{M})$ was added. After $6 \mathrm{~min}$. of incubation at $30^{\circ} \mathrm{C}$ the absorbance at $734 \mathrm{~nm}$ was measured using a Multiscan Ascent plate reader. The concentration of $\mathrm{ABTS}^{\bullet}$ was calculated using a molar extinction coefficient of $1.5 \times 10^{4} 25 \mathrm{mU} / \mathrm{sampleM}^{-1} \mathrm{~cm}^{-1}$. The reduction in $\mathrm{ABTS}^{\bullet}$ concentration was plotted against its initial concentration. The curve was fitted according to the exponential function $y=C\left(1-e^{(-b x)}\right)$ using Grafit (version 
3 ), where $y$ is the reduction in $\mathrm{ABTS}^{\bullet}$ concentration, $x$ the initial $\mathrm{ABTS}^{\bullet}$ concentration, and $C$ the maximal amount of ABTS ${ }^{\bullet}$ scavenged by the antioxidant at the concentration tested. Finally $C$, with a standard deviation calculated using Excel, is the average value of the ABTS ${ }^{\bullet}$ concentrations measured at least three times in duplicate using daily fresh diluted ABTS• solution.

\section{Statistical Analysis}

Data comparisons were made with the program Statistica 6.0. The median (M) and standard deviation (SD) were calculated for each group. The hypothesis of the equality of means was verified using Student $t$ test and nonparametric Wilcoxon test.

\section{Results and Discussion}

\section{Cytokine-Inducing Capability}

It was previously shown that PRP obtained from ovine colostrum by Janusz method and MPRP, obtained by Kruzel's methanol method, as well as one of its peptide components (NP) inhibit $A \beta$ aggregation, affect long-term memory, and increase neurite outgrowth (Popik et al. 1999, 2001; Basci et al. 2005; Schuster et al. 2005; Janusz et al. 2009). It was therefore of interest to compare their cytokine-inducing activity as well. The whole human blood cultures used in our experiments offer the advantage of reproducing the natural microenvironment of immunocompetent cells and provides the possibility to preserve intracellular communication between different cell populations (De Groote et al. 1992). MPRP of both ovine and bovine origin showed a lower inducing activity than PRP. In the doses used $(5-100 \mu \mathrm{g} /$ $\mathrm{ml})$, PRP induced the secretion of all the cytokines analyzed (IL-1 $\beta$, IL-6, IL-10, TNF- $\alpha$ ), although its inducing activity was lower than that of LPS + PHA $(2 \mu \mathrm{g}+2 \mu \mathrm{g})$ used as a positive control (Fig. 1a-d). Ovine and bovine MPRP induced, in a statistically significant manner, the secretion of only IL- $1 \beta$ and IL-6. However, the inducing capacity of MPRP was lower than that of PRP (Figs. 1a, b). With regard to IL-10 and TNF- $\alpha$, MPRP showed an inducing activity only when as much as $100 \mu \mathrm{g}$ of the preparation was used in the test, and that was equivalent to the effect of $5 \mu \mathrm{g}$ of PRP (Fig. 1c, d).

Both resident cells and cells infiltrating the CNS, such as monocytes, $\mathrm{T}$ cells, and neutrophils, can release proand anti-inflammatory cytokines when activated. These cytokines act as modulators of neural and glial function. They can provide inflammatory signals, but can also act as signals for neuroprotection and brain repair (Steinman 2008). The cytokines IL-1 $\beta$, IL- 6 , and TNF- $\alpha$ can regulate synaptic plasticity and neurogenesis. As neuromodulators they may play a role in cognitive processes at the molecular level (Vitkovic et al. 2000; Harding et al. 2005; BruelJungerman et al. 2007; McAfoose and Baune 2009; Zhan et al. 2011; Ben Menachem-Zidon et al. 2011). TNF, under immunologically unchallenged conditions, is essential for memory and learning processes (Baune et al. 2008). IL-1 was shown to be involved in the modulation of synaptic plasticity, crucial to memory and learning processes in the developing brain (Avital et al. 2003; Goshen et al. 2007). The cytokine-inducing capability of colostrum-derived PRP, including MPRP, could be one of the possible mechanisms of its effects in AD. However, the obtained results suggest that higher doses of MPRP should be used to receive the same results.

\section{Antioxidant Capacity of PRPs}

The antioxidant properties of PRP and MPRP preparations obtained from both ovine and bovine colostrum was assessed colorimetrically by the TEAC method. The troloxequivalent antioxidant capacity (TEAC) assay is a popular method for assessing the capacity of a compound to scavenge ABTS radicals. As presented in Table 1, the ovine and bovine MPRP preparations were able to scavenge comparable concentrations of $\mathrm{ABTS}^{\bullet}(8.32 \pm 8.6$ and $8.42 \pm 0.49$, respectively). However, the effects were weaker than those of the PRP preparations obtained from ovine and bovine colostra (14.12 \pm 2.79 and $13.96 \pm 1.98$, respectively) using the method of Janusz et al. (1981).

Besides the presence of valuable macro- and micronutrients, milk contains antioxidant factors. Whey protein hydrolysates, casein, and low-molecular casein-derived peptides are reported to have antioxidant activity (Laakso 1984; Suetsuna et al. 2000; Diaz et al. 2003). Several peptides with radical scavenging activity were also identified in $\alpha$-lactalbumin and $\beta$-lactoglobulin hydrolysates (Hernandez-Ledesma et al. 2005). The antioxidant properties of whey proteins can be increased through fractionation or hydrolysis with certain enzymes (Peňa-Ramos and Xiong 2001). Studies on the relationships between structure and antioxidant activity have been shown that the antioxidant capacity of the small peptides obtained by e.g. hydrolysis of white egg or milk proteins, can be related to their molecular mass, amino acid compositions, sequences, and hydrophobicities [Tang-Bin Zou et al. 2016]. A high content of amino acids like His, Trp, Phe, Pro, Gly, Lys, Ile and Val, and relative spatial structure of this amino acids in the peptide sequence is considered as the key factor in peptide ability to scavenge radicals. It was also observed that hydrolytic components with antioxidant activity were localized among peptides with relatively low molecular masses (lower than $<10 \mathrm{kDa}$ ) (Peňa-Ramos and Xiong 


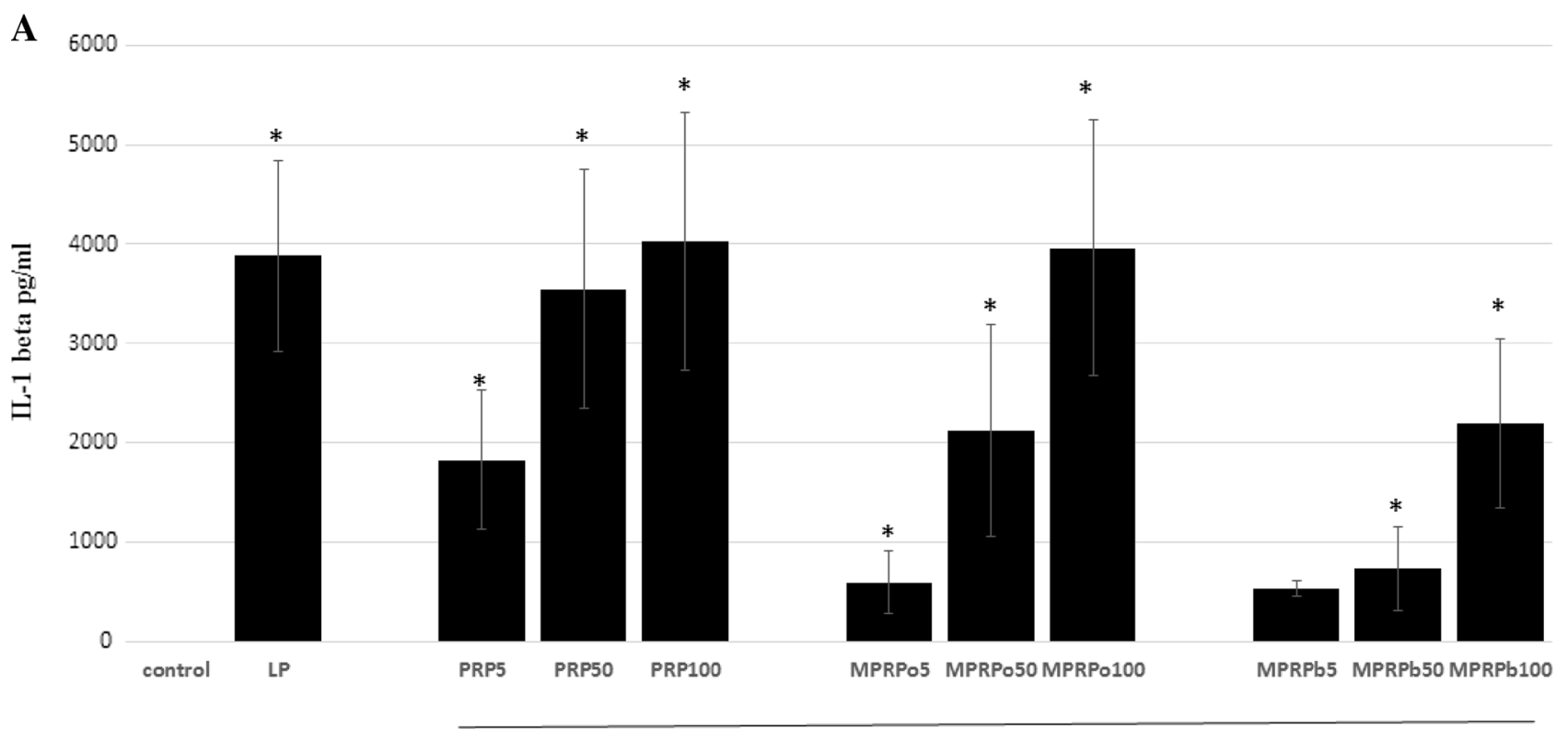

\section{$\mu \mathbf{g} / \mathbf{m l}$}

B

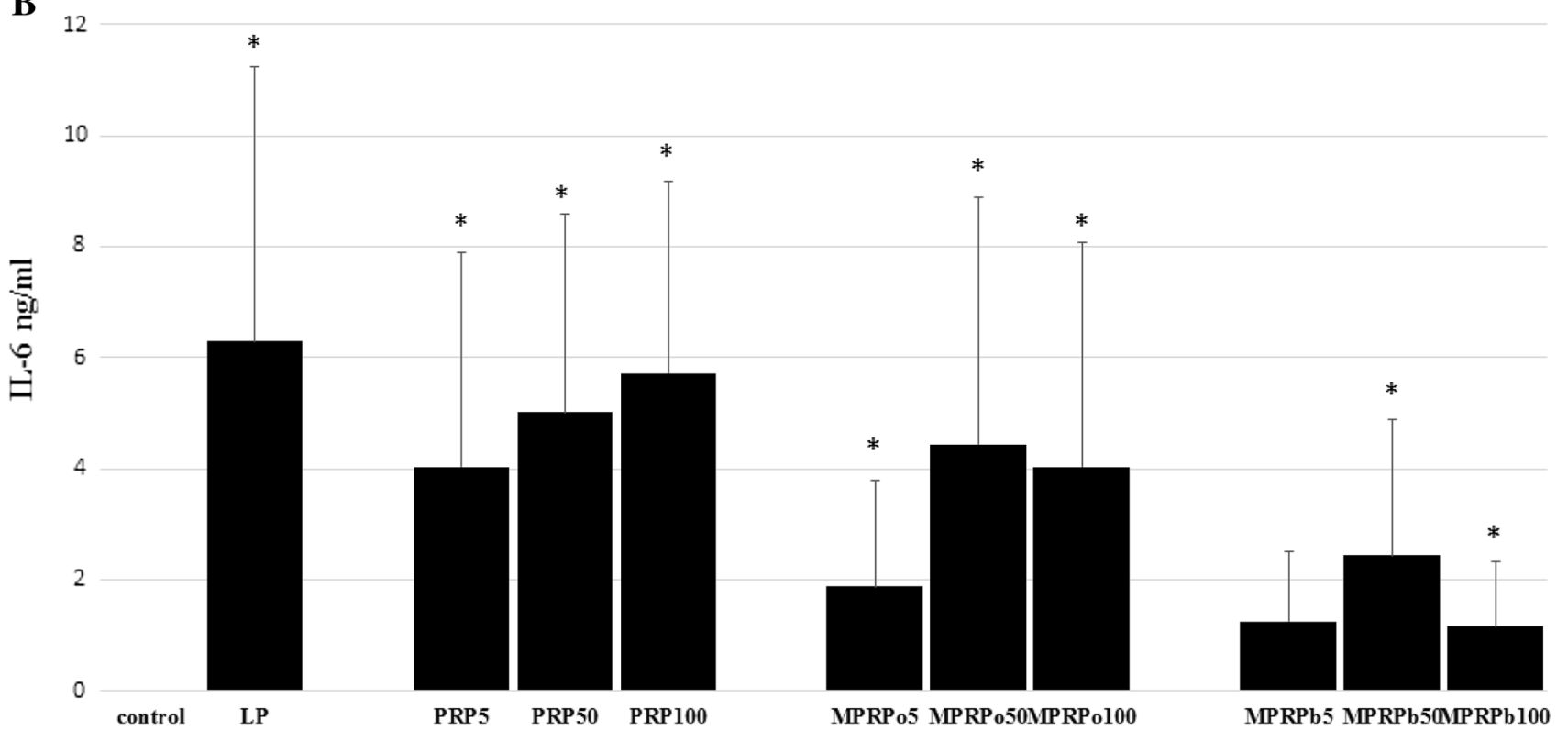

$\mu \mathrm{g} / \mathrm{ml}$

Fig. 1 Cytokine induction by PRP and ovine and bovine MPRP in cultures of human blood cells. 1-ml cultures of human whole blood, $10 \times$ diluted in RPMI 1640 medium supplemented with L-glutamine and antibiotics, were incubated with or without inducers for $22 \mathrm{~h}$ at $37{ }^{\circ} \mathrm{C}$ in a $5 \% \mathrm{CO}_{2}$ atmosphere. A mixture of LPS $(2 \mu \mathrm{g})$ and PHA $(2 \mu \mathrm{g})$, named LP, was used as a positive control. The inducers: PRP and $\mathrm{MPRP}_{\mathrm{o}}$ isolated from ovine colostrum, and $\mathrm{MPRP}_{\mathrm{b}}$ isolated from bovine colostrum were applied to the cells in doses of $5 \mu \mathrm{g} / \mathrm{ml}$ (PRP5,
$\mathrm{MPRP}_{\mathrm{o}}$ 5, MPRP 5 5), $50 \mu \mathrm{g} / \mathrm{ml}$ (PRP50, MPRP 50, MPRP ${ }_{\mathrm{b}}$ 50), and $100 \mu \mathrm{g} / \mathrm{ml}$ (PRP100, MPRP 100, MPRP $\left._{\mathrm{b}} 100\right)$. After incubation, the supernatants were collected and the levels of IL-1 $\beta$ (a), IL-6 (b), TNF- $\alpha(\mathbf{c})$, and IL-10 (d) were determined using ELISA. Results are expressed as the median $(M) \pm$ standard deviation (SD). Differences between samples were assumed to be significant at $\mathrm{p} \leq 0.05\left(^{*}\right)$; analyzed by non-parametric Wilcoxon test 
C 6000

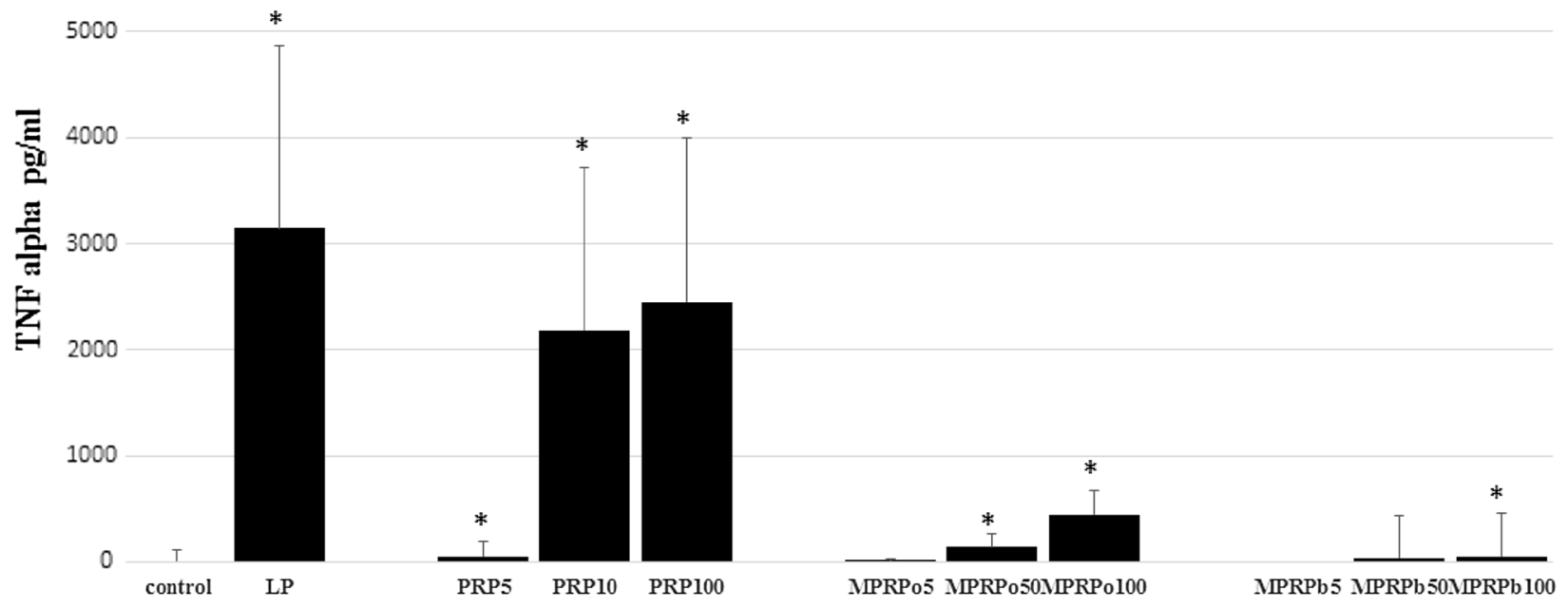

$\mu \mathrm{g} / \mathrm{ml}$

D

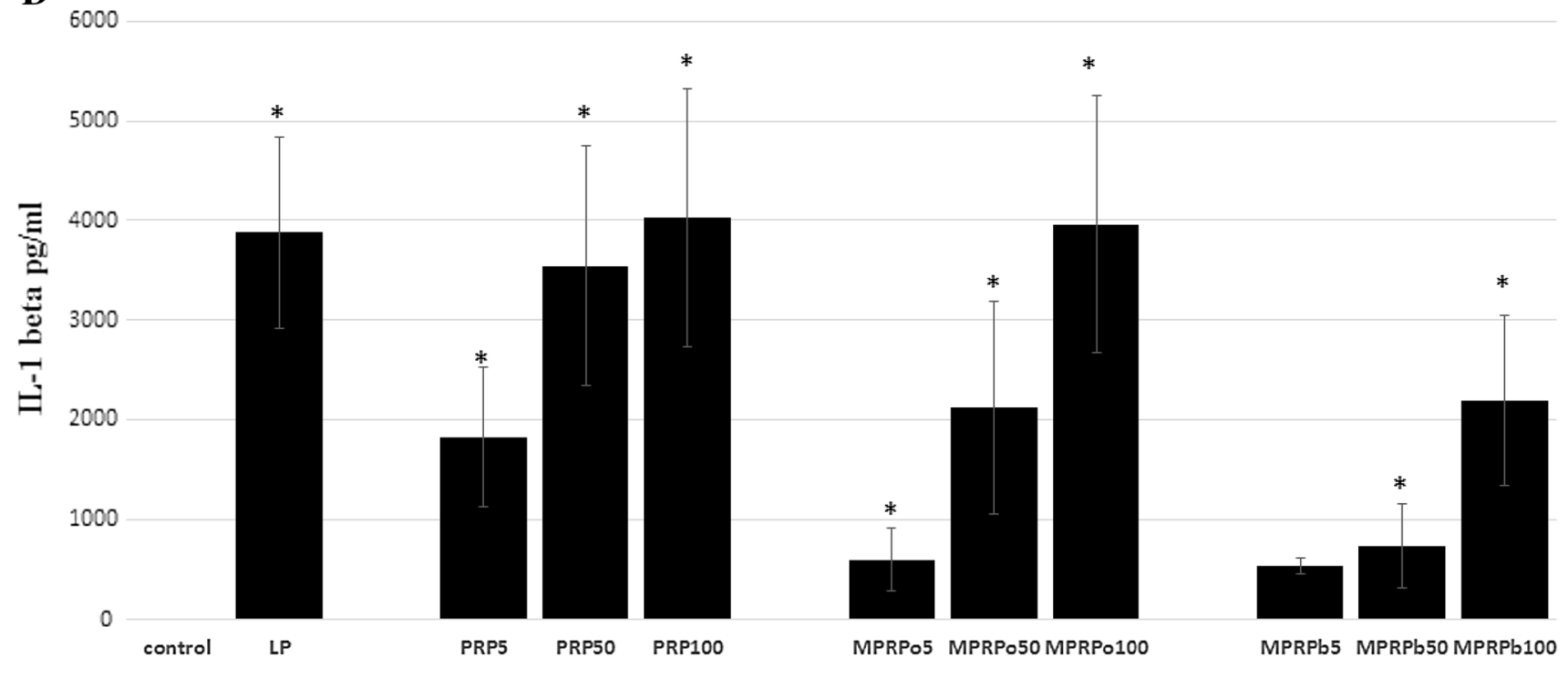

$\mu \mathrm{g} / \mathrm{ml}$

Fig. 1 (continued)

2001; Hernandez-Ledesma et al. 2005; Pihlanto 2006, Tang-Bin Zou et al. 2016). Both PRP and MPRP seems to belong to a group of low molecular weight antioxidants, and its antioxidant properties can be connected with its peptide composition and high concentration of proline (22\%) and hydrophobic amino acids (about 40\%). However, as was determined by Kruzel et al. (2004) small amount of higher molecular weight peptides $(<20 \mathrm{kDa})$ in MPRP was shown, what can be the reason of its weaker antioxidant activity (Fig. 2).

Oxidative stress is a key mechanism of $A \beta$-mediated neurotoxicity (Cheignon et al. 2018). The anti-oxidative activity of PRP is possibly responsible for its therapeutic effect in Alzheimer's disease. 
Table 1 Antioxidant capacities of PRP and MPRP preparations

\begin{tabular}{llll}
\hline $\begin{array}{l}\text { Potential } \\
\text { antioxi- } \\
\text { dant }\end{array}$ & Source & Isolation procedure & $\mathrm{C}_{\max }^{\mathrm{a}}(\mu \mathrm{M}) \pm \mathrm{SD}^{\mathrm{b}}$ \\
\hline $\mathrm{PRP}_{\mathrm{o}}$ & Ovine colostrum & Janusz et al. & $14.12 \pm 2.79$ \\
$\mathrm{PRP}_{\mathrm{b}}$ & Bovine colostrum & Janusz et al. & $13.96 \pm 1.98$ \\
$\mathrm{MPRP}_{\mathrm{o}}$ & Ovine colostrum & Methanol & $8.32 \pm 0.86$ \\
$\mathrm{MPRP}_{\mathrm{b}}$ & Bovine colostrum & Methanol & $8.42 \pm 0.49$ \\
\hline
\end{tabular}

Antioxidant capacities of preparations of $\mathrm{PRP}_{\mathrm{o}}$ and $\mathrm{MPRP}_{\mathrm{o}}$ isolated from ovine colostrum, and $\mathrm{PRP}_{\mathrm{b}}$ and $\mathrm{MPRP}_{\mathrm{b}}$ isolated from bovine colostrum was determined by TEAC method. The concentration of $\mathrm{ABTS}^{\bullet}$ was calculated using a molar extinction coefficient of $1.5 \times 10^{4} \mathrm{M}^{-1} \mathrm{~cm}^{-1}$. The reduction in ABTS ${ }^{\bullet}$ concentration was plotted against its initial concentration. The final $C_{\max }$ with standard deviation calculated using Excel is the average value of the ABTS concentration determined at least three times in duplicate

${ }^{\mathrm{a}} \mathrm{C}_{\max }$-maximal concentration of ABST scavenged by $1.25 \mu \mathrm{g}$ of PRP/MPRP

${ }^{\mathrm{b}} \pm \mathrm{SD}$ - standard deviation

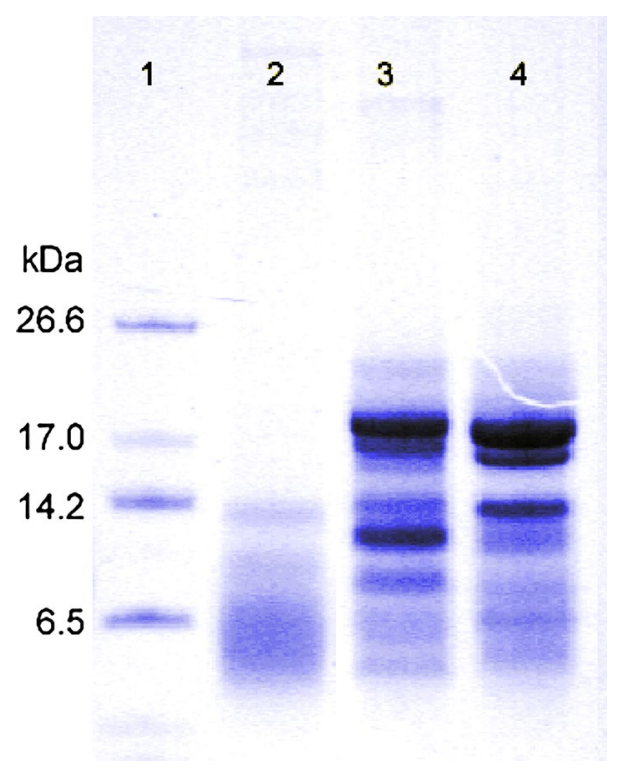

Fig. 2 SDS-PAGE analysis of PRP and MPRP isolated from ovine and bovine colostrum. Samples were rehydrated, assayed for protein content and equal amounts of protein were loaded to $15 \%$ SDS PAGE, followed staining with Coomassie blue R-250. (1)-MW molecular weight marker, (2) - $\mathrm{PRP}_{\mathrm{o}}$ obtained from ovine colostrum by Janusz et al. (3) - $\mathrm{MPRP}_{\mathrm{o}}$ and (4) $-\mathrm{MPRP}_{\mathrm{b}}$ obtained from ovine and bovine colostrum, respectively, by Kruzel et al.

\section{Effect on Nitric Oxide Release}

Neither PRP nor ovine and bovine MPRP induced NO release in the $\mathrm{J} 774$ cell cultures (data not shown). However, only PRP at a concentration of $100 \mu \mathrm{g} / \mathrm{ml}$ inhibited NO release induced by LPS (Fig. 3). No toxic effect of PRP or MPRP measured by trypan blue exclusion was observed at all doses used. An inhibitory effect of PRP at the applied doses of 1-100 $\mu \mathrm{g}$ on LPS-induced NO release in murine macrophages, and mice in vivo was shown in our previous experiments (Zabłocka et al. 2005). The present results show that MPRP at the doses used did not affect NO release. The concentration higher than $100 \mu \mathrm{g} / \mathrm{ml}$ of MPRP should probably be used.

\section{Conclusions}

Ovine and bovine MPRPs, like the PRP isolated on a laboratory scale using the method of Janusz et al. (1981), inhibited $\mathrm{A} \beta$ aggregation, improved memory function, were not species specific, and were active both in vivo and in vitro. They showed cytokine-inducing as well as antioxidant and NO inhibitory activities. It is suggested that both their antioxidant activity and their influence on cytokine and NO levels are rather connected with the lower-molecular-weight components of PRP complex. The efficacy of PRP concentration ranging from 5 to $100 \mu \mathrm{g} / \mathrm{ml}$ was previously shown in experiments on cultures of human whole blood cells, murine macrophages, and in mice in vivo (Inglot et al. 1996; Zabłocka et al. 2001, 2005, 2007). However, at the same concentration the activity of the MPRPs was lower than that of the PRP.

Comparison of amino acid composition of both PRP and MPRPs were found to be very similar. In particular, high level of proline residues (about 20\%) and hydrophobic amino acids were confirmed (Kruzel et al. 2004). However, comparison of the electrophoretic patterns and the RP-HPLC elution profiles of the PRP and MPRP preparations revealed the presence in the latter of additional larger-molecularweight peptides ( $>14 \mathrm{kDa}$ ) (Kruzel et al. 2004; Sokołowska et al. 2008). It can therefore be assumed that in examined MPRP doses (ranging from 5 to $100 \mu \mathrm{g} / \mathrm{ml}$ ) the percentage of low-molecular-weight peptides is lower than in PRP, which results from the presence of an additional fraction of peptides with a molecular weight above $14 \mathrm{kDa}$. To confirm this, additional tests with doses above $100 \mu \mathrm{g} / \mathrm{ml}$ should be carried out. 


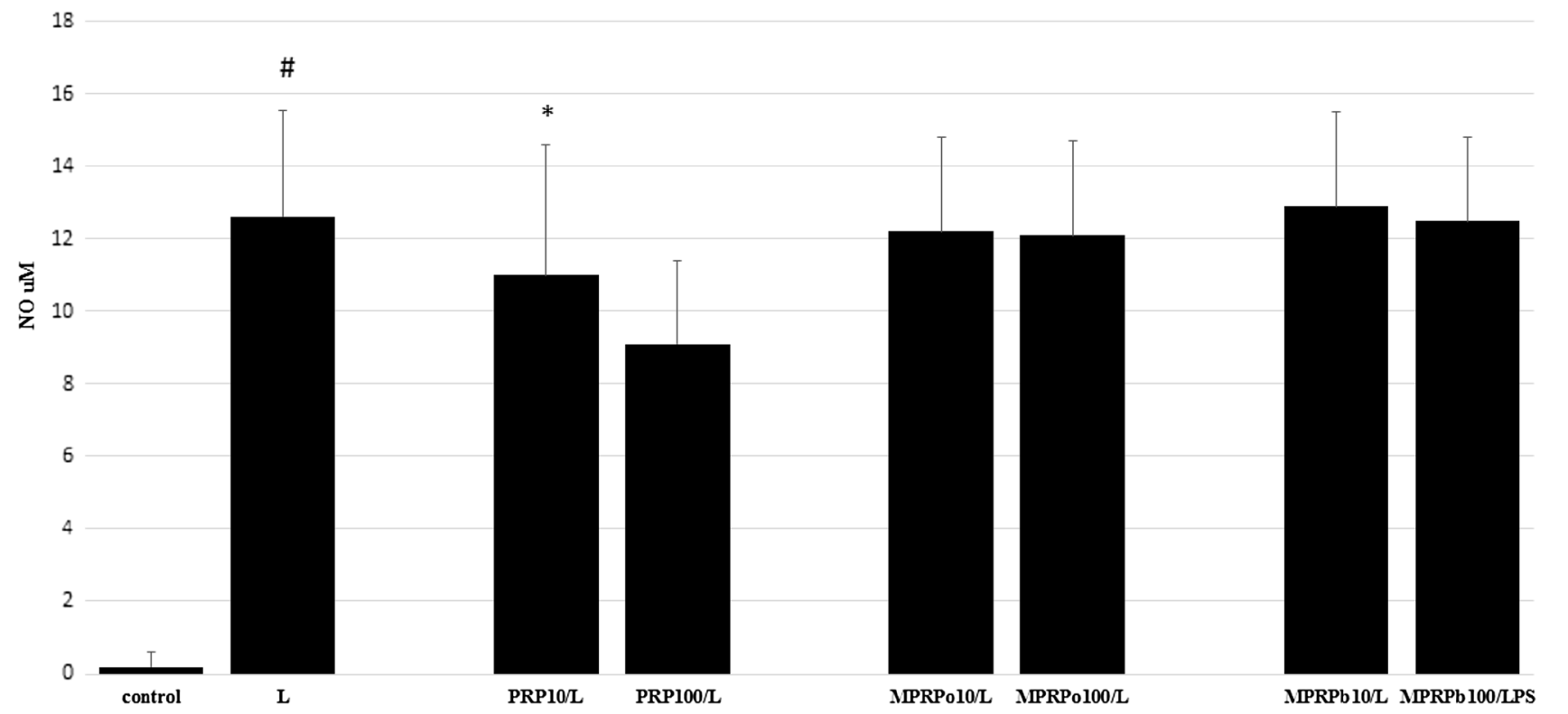

Fig. 3 The effect of PRP and MPRP on the regulation of nitric oxide (NO) production by the J774 macrophage cell line. J774 macrophages were stimulated with LPS $\left(1 \mu \mathrm{g} / 10^{6}\right.$ cells $\left./ \mathrm{ml}\right)$ (L) used as positive control. To check regulatory effect the inducers: PRP and MPRP isolated from ovine colostrum, and $\mathrm{MPRP}_{\mathrm{b}}$ isolated from bovine colostrum were applied to the cells in doses of $50 \mu \mathrm{g} / \mathrm{ml}\left(\mathrm{MPRP}_{\mathrm{o}} 10\right.$,
$\left.\mathrm{MPRP}_{\mathrm{b}} 10\right)$, and $100 \mu \mathrm{g} / \mathrm{ml}\left(\mathrm{MPRP}_{\mathrm{o}} 100, \mathrm{MPRP}_{\mathrm{o}} 100\right), 8 \mathrm{~h}$ after administration of LPS. Supernatants were collected $24 \mathrm{~h}$ after LPS administration and the NO level was determined as described in Materials and Methods. Data are mean \pm SD from three independent experiments. $* \mathrm{p} \leq 0.05$ significantly different from LPS alone; ${ }^{* *} \mathrm{p} \leq 0.05$ significantly different from control; analyzed by Student's $t$-test

\section{Compliance with Ethical Standards}

Conflict of interest All the authors who took part in this study declare that they have nothing to disclose regarding competing interest of funding from industry with respect to this manuscript.

Open Access This article is distributed under the terms of the Creative Commons Attribution 4.0 International License (http://creativeco mmons.org/licenses/by/4.0/), which permits unrestricted use, distribution, and reproduction in any medium, provided you give appropriate credit to the original author(s) and the source, provide a link to the Creative Commons license, and indicate if changes were made.

\section{References}

Aarli JA (2003) Role of cytokines in neurological disorders. Curr Med Chem 10:1931-1937

Arts MJ, Dallinga JS, Voss HP, Haenen GR, Bast A (2004) A new approach to assess the total antioxidant capacity using the TAEC assay. Food Chem 88:567-570

Avital A, Goshen I, Kamsler A, Segal M, Iverfeldt K, Richter-Levin G, Yirmiya R (2003) Impaired interleukin-1 signalling is associated with deficits in hippocampal memory processes and neural plasticity. Hippocampus 13:826-834

Barger SW, Horster D, Furukawa K, Goodman Y, Krieglstein J, Matson MP (1995) Tumor necrosis factors $\alpha$ and $\beta$ protect neurons against amyloid $\beta$ peptide toxicity. Proc Natl Acad Sci USA 92:9328-9332
Basci A, Stanton J, Hughes TK, Kruzel M, Boldogh I (2005) Colostrinin-driven neurite outgrowth requires p53 activation in PC12 cells. Cell Mol Neurobiol 25:1123-1138

Basci A, Woodberry M, Kruzel ML, Boldogh I (2007) Colostrinin delays the onset of proliferative senescence of diploid murine fibroblast cells. Neuropeptides 41:93-101

Baune BT, Wiede F, Braun A, Golledge J, Arolt V, Koerner H (2008) Cognitive dysfunction in mice deficient for TNF- $\alpha$ and its receptors. Am J Med Genet B 147B:1056-1064

Ben Menachem-Zidon O, Avital A, Ben-Menahem Y, Goshen I, Kreisel T, Shmueli EM, Segal M, Ben Hur T, Yirmiya R (2011) Astrocytes support hippocampal-dependent memory and long-term potentiation via interleukin-1 signaling. Brain Behav Immun 25:1008-1016

Bilikiewicz A, Gaus W (2004) Colostrinin (a naturally occurring, proline-rich, polypeptide mixture) in the treatment of Alzheimer's disease. J Alzheimer's Dis 6:17-26

Boldogh I, Kruzel ML (2008) Colostrinin ${ }^{\mathrm{TM}}$ : an oxidative stress modulator for prevention and treatment of age-related disorders. J Alzheimer's Dis 13:303-321

Boldogh I, Liebenthal D, Hughes TK, Juelich TL, Georgiades JA, Kruzel ML, Stanton GJ (2003) Modulation of 4HNE-mediated signaling by proline-rich peptides from ovine colostrum. J Mol Neurosci 20:125-134

Bourhim M, Kruzel M, Srikrishnan T, Nocotera T (2007) Linear quantitation of $\mathrm{A} \beta$ aggregation using Thioflavin T: reduction of fibril formation by colostrinin. J Neurosci Methods 160:264-268

Bruel-Jungerman E, Rampon C, Laroche S (2007) Adult hippocampal neurogenesis, synaptic plasticity and memory: facts and hypothesis. Rev Neurosci 18:93-114 
Cheignon C, Tomas M, Bonnefont-Rousselot D, Faller P, Hureau C, Collin F (2018) Oxidative stress and the amyloid beta peptide in Alzheimer's disease. Redox Biol 14:450-464

De Groote D, Zangerle PF, Gevaert Y, Fassotte MF, Beguin Y, NoizatPirenne J, Gathy R, Lopez M, Dehart I, Inglot D, Baudrihaye M, Delacroix D, Franchimont P (1992) Direct stimulation of cytokines (IL-1beta, TNF-alpha, IL-6, IL-2, IFN-gamma, and GM-CSF) in whole blood: I. Comparison with isolated PBMC stimulation. Cytokine 4:239-245

Diaz M, Dunn CM, McClements DJ, Decker EA (2003) Use of caseinophosphopeptides as natural antioxidants in oil-inwater emulsions. J Agric Food Chem 51:2365-2370

Goshen I, Kreisel T, Ounallah-Saad H, RenBaum P, Zalzstein Y, BenHur T, Levy-Lahad E, Yirmiya R (2007) A dual role for interleukin-1in hippocampal-dependent memory processes. Psychoneuroendocrinology 32:1106-1115

Guevara I, Iwanejko J, Dembińska-Kierc A, Pankiewicz J, Wanat A, Polus A, Gołąbek I, Bartuś S, Malczewska-Malec M, Szczudlik A (1998) Determination of nitrite/nitrate in human biological material by the simple Griess reaction. Clin Chim Acta 274:177-188

Harding D, Brull D, Humphries SE, Whitelaw A, Montgomery H, Marlow N (2005) Variation in the interleukin-6 gene is associated with impaired cognitive development in children born prematurely: a preliminary study. Pediatr Res 58:117-120

Hernandez-Ledesma B, Davalos A, Bartolome B, Amigo L (2005) Preparation of antioxidant enzymatic hydrolysates from a-lactalbumin and b-lactoglobulin. Identification of active peptides by HPLC-MS/MS. J Agric Food Chem 53:588-593

Inglot AD, Janusz M, Lisowski J (1996) Colostrinine: a proline-rich polypeptide from ovine colostrum as a modest cytokine inducer in human leukocytes. Archivum Immunologiae et Therapiae Experimentalis 44:215-224

Janusz M, Lisowski J (1993) Proline-rich polypeptide (PRP)—an immunomodulatory peptide from ovine colostrum. Archivum Immunologiae et Therapiae Experimentalis 41:275-279

Janusz M, Lisowski J, Franek F (1974) Isolation and characterization of a proline-rich polypeptide from ovine colostrum. FEBS Lett 49:276-279

Janusz M, Starościk K, Zimecki M, Wieczorek Z, Lisowski J (1981) Chemical and physical characterization of a proline-rich polypeptide from sheep colostrum. Biochem J 199:9-15

Janusz W, Woszczyna M, Lisowski M, Kubis A, Macała J, Gotszalk T, Lisowski J (2009) Ovine colostrum nanopeptide affects amyloid beta aggregation. FEBS Lett 583:190-196

Kruzel ML, Polanowski A, Wilusz T, Sokołowska A, Pacewicz M, Bednarz R, Georgiades J (2004) The alcohol-induced conformational changes in casein micelles: a new challenge for the purification of Colostrinin. Protein J 23:127-133

Kubis A, Marcinkowska E, Janusz M, Lisowski J (2005) Studies on the mechanism of action of a proline-rich polypeptide complex (PRP): effect on the stage of cell differentiation. Peptides 26:2188-2192

Laakso S (1984) Inhibition of lipid peroxidation by casein. Evidence of molecular encapsulation of 4,4-pentadiene fatty acids. Biochem Biophys Acta 792:11-15

Leszek J, Inglot AD, Janusz M, Lisowski J, Krukowska K, Georgiades J (1999) Colostrinin ${ }^{\circledR}$ : a proline-rich polypeptide (PRP) comple isolated from ovine colostrum for treatment of Alzheimer's disease. A double-blind, placebo-controlled study. Archivum Immunologiae et Therapiae Experimentalis. 47:377-385

Leszek J, Inglot AD, Janusz M, Byczkiewicz F, Kiejna A, Georgiades J, Lisowski J (2002) Colostrinin ${ }^{\circledR}$ proline-rich polypeptide complex from ovine colostrum-a long-term study of its efficacy in Alzheimer's disease. Med Sci Monit 8:93-96
Lindberg C, Selenica ML, Westlind-Danielsson A, Schultzberg M (2005) Beta-amyloid protein structure determinates the nature of cytokine release from rat microglia. J Mol Neurosci 27:1-12

Lovell MA, Ehmann WD, Mattson MP, Markesbery WR (1997) Elevated 4-hydroxynonenal in ventricular fluid in Alzheimer's disease. Neurobiol Agening 18:457-461

Lynch MA (2014) The impact of neuroimmune changes on development of amyloid pathology; relevance to Alzheimer's disease. Immunology 141:292-301

Maccioni RB, Munoz JP, Barbeito L (2001) The molecular basis of Alzheimer's disease and other neurodegenerative disorders. Arch Med Res 32:367-381

Mattson MP (2004) Pathways towards and away from Alzheimer's disease. Nature 430:631-639

McAfoose J, Baune BT (2009) Evidence for a cytokine model of cognitive function. Neurosci Biobehav Rev 33:355-366

Moshage H, Kok B, Huizenga JR, Jansen PLM (1995) Nitrite and nitrate determinations in plasma: a clinical evaluation. Clin Chem 41:892-896

Parihar MS, Hemnani T (2004) Alzheimer's disease pathogenesis and therapeutic interventions. J Clin Neurosci 11:456-467

Peňa-Ramos EA, Xiong Y (2001) Antioxidative activity of whey protein hydrolysates in liposomal system. J Dairy Sci 84:2577-2583

Piasecki E, Inglot AD, Winiarska M, Krakowska K, Janusz M, Lisowski J (1997) Coincidence between spontaneous release of interferon and tumor necrosis factor by colostral leukocytes and production of colostrinine by human mammary gland after norma delivery. Archivum Immunologiae et Therapiae Experimentalis 45:109-117

Pihlanto A (2006) Antioxidative peptides derived from milk proteins. Int Dairy J 16:1306-1314

Popik P, Bobula B, Janusz M, Lisowski J, Vetulani J (1999) Colostrinin, a polypeptide isolated from early milk, facilities learning and memory in rats. Pharmacol Biochem Behav 1:183-189

Popik P, Galoch Z, Janusz M, Lisowski J, Vetulani J (2001) Cognitive effects of Colostral-Val nonapeptide in aged rats. Behav Brain Res 118:201-208

Schuster D, Rajendran A, Hui SW, Nicotera T, Srikrishnan T, Kruzel ML (2005) Protective effect of colostrinin on neuroblastoma cell survival is due to reduced aggregation of $\beta$-amyloid. Neuropeptides 39:419-426

Sokołowska A, Bednarz R, Pacewicz M, Georgiades JA, Wilusz T, Polanowski A (2008) Colostrum from different mammalian species-A rich source of colostrinin. Int Dairy J 18:204-209

Stanton GJ, Boldogh IS, Georgiades JA, Hughes TK (2001) Induction of proliferation and cytokines by Colostrinin ${ }^{\circledR}$ and component proline-rich peptides in human peripheral blood leukocytes. Yearb Psychogeriatr 4:67-75

Steinman L (2008) Nuanced roles of cytokines in three major human brain disorders. J Clin Investig 118:3557-3563

Steward MG, Banks D (2006) Enhancement of long-term memory retention by Colostrinin in one-day-old chicks trained on a weak passive avoidance learning paradigm. Neurobiol Learning Mem 86:66-71

Suetsuna K, Ukeda H, Ochi H (2000) Isolation and characterization of free radical scavenging activities peptides derived from casein. $\mathbf{J}$ Nutr Biochem 11:128-131

Vitkovic L, Bockaert JJ, Jacque C (2000) Inflammatory cytokines: neuromodulators in the normal brain? J Neurochem 74:457-471

Vitkovic L, Maeda S, Sternberg E (2001) Anti-inflammatory cytokines: expression and action in the brain. NeuroImmunoModulation 9:295-312

Wang X, Wang W, Li L, Perry G, Lee HG, Zhu X (2014) Oxidative stress and mitochondrial dysfunction in Alzheimer's disease. Biochim Biophys Acta. 1842(8):1240-1247 
Weiner MW, Veitch DP, Aisen PS, Beckett LA, Cairns NJ, Green RC, Harvey D, Jack CR Jr, Jagust W, Morris JC, Petersen RC, Saykin AJ, Shaw LM, Toga AW, Trojanowski JQ (2017) Recent publications from the Alzheimer's Disease Neuroimaging Initiative: reviewing progress toward improved AD clinical trials. Alzheimers Dement 13:e1-e85

Zabłocka A, Janusz M (2012) Effect of proline-rich polypeptide complex/Colostrinin ${ }^{\mathrm{TM}}$ on the enzymatic antioxidant system. Arch Immunol Ther Exp 60:383-390

Zabłocka A, Janusz M, Rybka K, Wirkus-Romanowska I, Kupryszewski G, Lisowski J (2001) Cytokine-inducing activity of a proline-rich polypeptide complex (PRP) from ovine colostrum and its active nonapeptide fragment analogs. Eur Cytokine Netw $12: 456-467$

Zabłocka A, Janusz M, Macała J, Lisowski J (2005) A proline-rich polypeptide complex and its nonapeptide fragment inhibit nitric oxide production induced in mice. Regul Pept 125:35-39

Zabłocka A, Janusz M, Macała J, Lisowski J (2007) A proline-rich polypeptide complex (PRP) isolated from ovine colostrums. Modulation of $\mathrm{H}_{2} \mathrm{O}_{2}$ and cytokine induction in human leukocytes. Int Immunopharmacol 7:981-988
Zabłocka A, Urbaniak A, Kuropatwa M, Zyzak J, Rossowska J, Janusz M (2014) Can proline-rich polypeptide complex mimic the effect of nerve growth factor? BioFactors 40:501-512

Zhan L, Yi-Hua Q, Bing L, Ma S-H, Peng Y (2011) Neuroprotection of interleukin-6 against NMDA-induced apoptosis and its signaltransduction mechanism. Neurotoxicol Res 19:484-485

Zhu X, Raina AK, Lee HG, Casadesus G, Smith MA, Perry G (2004) Oxidative stress signalling in Alzheimer's disease. Brain Res 1000:32-39

Zou T-B, He T-P, Li H-B, Tang H-W, Xia E-Q (2016) The structureactivity relationship of the antioxidant peptides from natural proteins. Molecules 21:72

Publisher's Note Springer Nature remains neutral with regard to jurisdictional claims in published maps and institutional affiliations. 